Yechiel Y. Schur

\title{
'When the Grave was Searched, the Bones of the Deceased were not Found': Corporeal Revenants in Medieval Ashkenaz
}

\author{
Dear dead! - Not as before will Elijah come \\ To stretch out upon you with burning lips and eyes. \\ You are cold. No voice cries out. There is not one to listen. \\ And you will never rise. \\ Rahel, 'Elijah’1
}

\section{Introduction}

Reassuring and comforting indeed is the biblical scene about Elijah resuscitating the deceased child. But as the poet Rahel touchingly reminds us, this biblical scene is but a heartening fantasy; in real life the dead remain dead and will never come back. Or will they?

The belief that the dead will come alive in the unknown future has been traditionally regarded as a foundational religious belief in Judaism, and various tenets of this belief are shared by Christianity and Islam. ${ }^{2}$ According to the Mishna, a person who denies this belief has no share in the world to come. ${ }^{3}$ In their efforts to validate the belief in the resurrection of the dead, and in large part in response to sectarian groups who denied this belief, the sages of the Talmud marshalled various verses as prooftexts for this religious tenet.

Medieval Jewish thinkers, most notably Sa'adya and Maimonides, elaborated the theme of the resurrection of the dead far more extensively than earlier writers. Sa'adya devotes an entire chapter in his Book of Doctrines and Beliefs to discussing the concept of bodily resurrection ${ }^{4}$ and Maimonides discusses it

1 Flowers of Perhaps, Eng. trans. by Robert Friend and Shimon Sandbank (New Milford, CT: Toby Press, 2008), p. 51. I thank Ephraim Kanarfogel, Yonatan Moss, Amnon Raz-Krakotzkin, Sabine Schmidtke, and Galili Shahar for reading an earlier draft of this article.

2 For Christianity, see Caroline W. Bynum, Resurrection of the Body in Western Christianity, 200-1336 (New York: Columbia University Press, 1995). For Islam, see Jane I. Smith and Yvonne Y. Haddad, The Islamic Understanding of Death and Resurrection (Oxford; New York: Oxford University Press, 2002), esp. pp. 31-61. I thank Sabine Schmidtke for this latter reference.

3 mSanh. 10.1, ed. by Ch. Albeck (Tel Aviv: Devir, 1953), p. 202.

4 Sa'adya Gaon, The Book of Beliefs and Opinions, Treatise VII, Eng. trans. by Samuel Rosenblatt (New Haven: Yale University Press, 1948), pp. 264-89. On Sa‘adya, see Arthur Hyman, 
in his Mishne Torah, the Commentary on the Mishna, and in a treatise devoted exclusively to this topic, commonly known as the Treatise on Resurrection. ${ }^{5}$

One commonality in the texts about the resurrection of the dead written by these two Jewish philosophers is that they have treated the topic as part of a broader discussion of the days to come and the messiah. Sa'adya's chapter on the resurrection precedes a chapter on redemption whereas Maimonides' discussion in the Commentary on the Mishna appears in his introduction to the tenth chapter of Tractate Sanhedrin, where he extensively expands the talmudic discussion about the world to come.

The various and somewhat contradictory statements of Maimonides, in particular, about the resurrection of the dead have led scholars to debate his real stance regarding the belief in a bodily resurrection. On the one hand, Maimonides famously claims in his Commentary on the Mishna that the delights of the soul are everlasting and uninterrupted, and there is no resemblance in any possible way between spiritual and bodily enjoyments.' 6 Similarly, since according to the Mishne Tora, there are in the other-world no 'bodies and forms, but souls of the righteous only without body, like the angels on high', 7 the concept of bodily resurrection is rendered futile and meaningless. On the other hand, Maimonides affirms in his Treatise on Resurrection and elsewhere the traditional rabbinic belief in bodily resurrection, thereby echoing his

Eschatological Themes in Medieval Jewish Philosophy (Milwaukee, Wis.: Marquette University Press, 2002), pp. 45-51; Steven Harvey, 'Logistical and Other Otherworldly Problems in Saadya', in Esoteric and Exoteric Aspects in Judeo-Arabic Culture, ed. by Benjamin Hary and Haggai Ben-Shammai (Leiden; Boston: Brill, 2006), pp. 55-84; Henry Malter, Saadia Gaon: His Life and Works (Philadelphia: Jewish Publication Society, 1942), pp. 230-37. Note that the definition of the resurrection of the dead as an occurrence that '[...] will take place in this world of ours as a natural phenomenon' in Malter's discussion of the seventh chapter of Sa'adya's Book of Opinions and Beliefs (p. 231 in Malter's book) differs from the way the phenomenon of revenants is understood in this paper. Malter means that the resurrection will take place in this world rather than in the world to come but still maintains an eschatological dimension with regard to the question as to when the resurrection of the dead will occur.

5 On Maimonides, see Hyman, Eschatological Themes, pp. 75-79; Albert Friedberg, 'Maimonides' Reinterpretation of the Thirteenth Article of Faith: Another Look at the Essay on Resurrection', Jewish Studies Quarterly, 10:3 (2003), pp. 244-55; Alexandra Wright, 'Immortality and Resurrection: Maimonides and the Maimonidean Controversy', Aspects of Liberal Judaism, ed. by David J. Goldberg and Edward Kessler (London; Portland, OR: Vallentine Mitchell, 2004), pp. 159-69. I thank my Penn colleague Marc Herman for sharing with me his unpublished article 'Evaluating Maimonides' Treatise on Resurrection.'

6 Maimonides, Commentary on the Mishna, vol. 4, Heb. trans. by Yosef Kafah (Jerusalem: Mosad Harav Kook, 1965), pp. 204-205. See Joshua Abelson, 'Maimonides on the Jewish Creed', Jewish Quarterly Review, 19:1 (1906), p. 38.

7 Maimonides, Mishne Torah, Laws of Repentance, 8.2. 
commitment to the traditional view, which may be the result of his religious role in the Jewish community as a major halakhic figure and communal leader.

Without attempting to reconcile the seeming contradictions in Maimonides' treatment of the resurrection of the dead, it becomes evident that, by considering bodily resurrection in the context of the days to come and the messianic period, Maimonides was able to remain, perhaps intentionally, vague and inconclusive. Only in the unknown future will the exact nature of the days to come become clear and, therefore, one is advised not to spend much time worrying about such issues as the nature of the messianic period and the world to come. ${ }^{8}$

Modern scholars have also conventionally treated the topic of bodily resurrection in the context of eschatological and messianic beliefs. To mention but one example, E. E. Urbach situates the bulk of the discussion about the resurrection of the dead in the book's last chapter under the title 'On Redemption'. Resurrection is grouped with topics such as redemption, apocalyptical literature, and messianism in ancient Judaism. ${ }^{9}$ This tendency is easily identified in many other scholarly discussions of resurrection in biblical, ${ }^{10}$ talmudic, ${ }^{11}$ and medieval texts. ${ }^{12}$

The association of bodily resurrection with eschatology and the days to come is so common that it is nearly impossible to deal with the topic in any other way. But, historically speaking, people in pre-modern society commonly accepted the phenomenon of the dead coming back to life not merely as part of a traditional belief in the resurrection of the dead, but as part of everyday experience. With regard to Western Europe during the Middle Ages, several studies have shown the commonality of beliefs in revenants (the dead coming undead) and, more generally, the acceptance of beliefs in frequent encounters between the living and the dead.13

8 Maimonides, Mishne Torah, Laws of Kings and Wars, 12.2.

9 Ephraim E. Urbach, The Sages, Their Concepts and Beliefs, Eng. trans. by Israel Abrahams (Cambridge, MA.: Harvard University Press, 1987), pp. 649-92; pp. 990-1009.

10 Lloyd R. Bailey, Biblical Perspectives on Death (Philadelphia: Fortress Press, 1979), pp. 73-4. 11 Jacob Neusner, 'Death and Afterlife in the Later Rabbinic Sources: The Two Talmuds and Associated Midrash-Compilations', in Judaism in Late Antiquity, vol. IV (Leiden, New York: E. J. Brill, 2000), pp. 267-91.

12 Julius Guttmann, Philosophies of Judaism: The History of Jewish Philosophy from Biblical Times to Franz Rosenzweig, Eng. trans. by David W. Silverman (New York: Schocken, 1973), pp. 82-83.

13 See Ronald C. Finucane, Appearances of the Dead: A Cultural History of Ghosts (London: Junction Books, 1982), esp. pp. 29-89; Aaron Gurevich, Historical Anthropology of the Middle Ages, ed. Jana Howlett (Chicago: University of Chicago Press, 1992), esp. pp. 65-89; Nancy Caciola, 'Wraiths, Revenants and Ritual in Medieval Culture', Past and Present, 152 (1996), pp. 3-45; Jean-Claude Schmitt, Ghosts in the Middle Ages: The Living and the Dead in Medieval 
In this paper I argue that medieval Jews, like their non-Jewish counterparts, believed in the phenomenon of revenants. Like Christians, Jews believed that a dead person could come alive in the relatively near future after that person's demise (as opposed to returning in the unknown eschatological time frame). Moreover, like Christians, some Jews believed that a revenant comprised actual corporeal elements of the deceased, rather than a spiritual entity, such a ghost, which may appear as a human being but is lacking any actual corporeal elements.

I also submit that a belief in the phenomenon of revenants was held by the rabbinic elite and not merely by ordinary, 'superstitious' folk. This contention is in line with other studies on medieval Ashkenaz that have called into question any bifurcated division between the elite and the populace. ${ }^{14}$ Such a scholarly effort at challenging the two-tiered distinction between the perceptions of the elite and those of the populace is also apparent in more general works on pre-modern society. ${ }^{15}$ As Peter Brown has shown in a different context, the two-tiered model can rarely be sustained and is rather a scholarly construct with limited correspondence to the historical reality of late antiquity or medieval Europe. ${ }^{16}$

My focus on revenants in medieval Ashkenaz stems from two reasons. First, the exegetical approach known as peshat and championed by a number of Ashkenazi scholars lends itself to interpreting biblical passages about the undead in a more literal and factual way than, for example, the alternative

Society, Eng. trans. Teresa L. Fagan (Chicago: University of Chicago Press, 1998). For a discussion of the phenomenon of revenants in a later period, see Paul Barber, Vampires, Burial and Death: Folklore and Reality (New Haven: Yale University Press, 1988).

14 See Avriel Bar-Levav, 'Death and the (Blurred) Boundaries of Magic: Strategies of Coexistence,' in Kabbalah: Journal for the Study of Jewish Mystical Texts, 7 (2002), pp. 51-64; idem, 'We are Where We are Not: The Cemetery in Jewish Culture,' in Jewish Studies, 41 (2002), pp. 15-46; Moshe Idel, Golem: Jewish Magical and Mystical Traditions on the Artificial Anthropoid (Albany, N.Y.: State University of New York Press, 1990), esp. pp. 57-80; Ephraim Kanarfogel, Peering Through the Lattices: Mystical, Magical, and Pietistic Dimensions in the Tosafist Period (Detroit: Wayne State University Press, 2000); Dov Schwartz, Astral Magic in Medieval Jewish Thought (Hebrew; Ramat Gan: Bar Ilan University Press, 1999); David Shyovitz, "'He Has Created a Remembrance of His Wonders': Nature and Embodiment in the Thought of the Hasidei Ashkenaz" (Philadelphia: doctoral dissertation, University of Pennsylvania, 2011).

15 Robert Darnton, The Great Cat Massacre and Other Episodes in French Cultural History (New York: Basic Books, 1984); Carlo Ginzburg, The Cheese and the Worms: The Cosmos of a Sixteenth-century Miller, Eng. trans. by John and Anne Tedeschi (Baltimore: Johns Hopkins University Press, 1980).

16 Peter Brown, The Cult of the Saints: Its Rise and Function in Latin Christianity (Chicago: University of Chicago Press, 1981). 
exegetical approaches of various commentators from medieval Spain. ${ }^{17}$ Furthermore, even specific references to the resurrection of the dead in rabbinic texts are treated by Ashkenazi scholars (most notably by Moshe Taku) in a manner that is more factual and empirical than that found in parallel discussions of the topic by Sefardi thinkers. ${ }^{18}$

\title{
2 Corporeal revenants
}

In a short anonymous treatise from Ashkenaz on the use of Divine names for conjurations (hashba'ot), we find the following intriguing passage:

\begin{abstract}
Said R. Yișhaq: It occurred that Eliyahu, the son of R. Todros from the town of Qeranot ${ }^{19}$, was killed at the age of twenty inside the city. The son was buried promptly while the father was away but when the father returned he refused to eat or drink anything until the great sages, R. Ya'aqov [b. Meir] of Ramerupt and R. Eliyahu [b. Yehuda] of Paris permitted him to call upon (le-ha'alot le-fanaw) his son by using the Divine Name in the presence of the entire community [...] After receiving the consent of the rabbis, the father immersed himself in a ritual bath, wore white clothes and, together with the community, fasted on a Thursday ${ }^{20}$ and went to the synagogue. Having inserted the Name between the Torah scrolls [inside the Holy Ark], the father conjured up the deceased son after which the son appeared between the Torah scrolls. Having removed his son (we-laqah beno le-horido) from the Holy Ark with the entire community witnessing, the father spoke to the son as the father had wished and then returned him (hehziro) back to the Holy Ark $[\ldots]^{21}$
\end{abstract}

Relating the moving story of a father who could not attend his son's funeral and wished to bid farewell to the deceased son, the text raises several issues

17 See Sarah Kamin, Rashi: Peshuțo shel Miqra u-Midrasho shel Miqra (Jerusalem: The Magnes Press, 1986); Sara Japhet, Dor Dor u-Parshanaw: Asufat Mehqarim Be-Parshanut Ha-Miqra, Asufot 1 (Jerusalem: Mosad Bialik, 2008), pp. 133-309. For a recent comparison of the different exegetical approaches in Spain and Ashkenaz, see Eric Lawee, 'The Reception of Rashi's Commentary on the Torah in Spain: The Case of Adam's Mating with the Animals', Jewish Quarterly Review, 97:1 (2007), pp. 33-66.

18 Compare the discussion of the resurrection of the dead in Moshe Taku's Ketav Tamim with Maimonides' Treatise on Resurrection. Ketav Tamim, ed. by Joseph Dan (Jerusalem: The Dinur Center, 1984); Treatise on Resurrection, in Crisis and Leadership: Epistles of Maimonides, ed. and trans. by Abraham Halkin and David Hartman (Philadelphia: Jewish Publication Society, 1985), pp. 211-33; 233-45.

19 This is the Hebrew spelling of the place but, regrettably, I am unable at this point to identify the town.

20 mTa'an. 1.4.

21 Kanarfogel, Peering Through the Lattices, p. 171. 
noted in previous scholarly discussions. Most apparently, it attests to the involvement of Ashkenazi authorities in magical activities. In addition to the activity described here, other forms of magic were attributed to R. Todros. ${ }^{22}$ R. Eliyahu of Paris was known for his piety and the use of mystical traditions concerning the end of days. But even such a normative authority as R. Ya'aqov b. Me'ir of Ramerupt (commonly referred to as 'Rabbenu Tam') ruled in favour of this mysterious practice. Moreover, what seems like an esoteric practice - the use of a Divine name for calling upon a dead person - was not done privately in a hidden place but in public, in front of the entire community, thus undermining the possible classification of the ritual as an esoteric kabbalistic activity performed in secrecy.

One additional, and rather unnoticed aspect of the text is the corporeality of the revived son. While it is not possible to know from this text the 'matter' from which the undead son was made (that is, spiritual elements only, ${ }^{23}$ or real flesh and blood), the verbs employed to convey how the father interacted with his son by physically removing him from the holy ark and returning him there arguably allude to some form of corporeal existence.

If the corporeal essence of the undead son may seem at least speculative, if not unimaginable, additional texts from medieval Ashkenaz confirm this interpretation and show that at least some Ashkenazi Jews believed in the phenomenon of corporeal revenants. But before considering the medieval textual evidence, it is necessary to consider briefly and generally biblical and post-biblical references to post-mortem existence.

In the Hebrew Bible at least two different views concerning post-mortem existence may be identified. According to one approach, life is the joining of body and spirit and death is the separation of the two. With the departure of the soul, the body 'returns to the ground' and the soul 'returns to God who bestowed it.' 24 The rewards and punishments mentioned in the Bible are commonly promised in this world, with few instances of otherworldly incentives for obeying God or of otherworldly punishments for disobeying Him. But the Bible also alludes to various forms of post-mortem existence such as resurrec-

22 See reference in ibid, p. 171, no. 96.

23 This is suggested by Kanarfogel who refers to the miraculous incident as a resurrection of '(the image of) the son' but how can an image be resurrected? Although the word 'resurrection' would have been in line with my interpretation of the text as a revival of an embodied figure, and not merely the revival of an image, I refrained from using the word in my translation since the corresponding Hebrew words tehiyya (see Ezek 37:3) or le-haqiṣ (see Dan 12:2) do not appear in the Hebrew text.

24 Eccl 12:7. 
tion of the dead ('many of those that sleep in the dust of the earth will awake' ${ }^{25}$ ), the underworld (she'ol) ${ }^{26}$, and the prohibition on any communication with the dead. ${ }^{27}$ In addition, there are several scriptural stories of dead people returning to life, most notably the episode about Samuel and the medium in Endor (I Samuel 28) to which I shall return later. These instances demonstrate deep familiarity with, and awareness of, the world of the dead, although, in comparison with references to post-mortem existence in postbiblical texts, the Bible has relatively little to say about the otherworld. ${ }^{28}$

References in rabbinic texts to various forms of post-mortem existence are legion. ${ }^{29}$ Among the many expressions of such beliefs are the various passages about bodily resurrection of the dead in the days to come ${ }^{30}$; the soul visiting the body of the deceased during the first twelve months after death ${ }^{31}$; and several stories about dead people appearing to the living as ghosts. ${ }^{32}$ The rabbis clearly not only formulated and constructed their theoretical views of postmortem existence but prescribed some concrete halakhic requirements directly related to their perceptions of death. For instance, they prohibited the conducting of certain rituals in the vicinity of the dead, since this is regarded as teasing the dead who are unable to partake in religious rituals. The Talmud formally grounds this prohibition in the dictum 'worms are as painful to the dead as a needle in the flesh of the living', ${ }^{33}$ thus asserting that the deceased are capable of sensing physical pain.

Nevertheless, in spite of the engagement of ancient Jewish sages with issues pertaining to life after death, the evidence about their belief in the existence of corporeal revenants is rather limited. This assertion may be explained through the rabbinic discussion of the appearance of Samuel to the necromancer in Endor - arguably the most pronounced encounter with the undead in the Bible - where very little is said about the nature of the revealed prophet. The rabbis mention that due to Saul's elevated status the dead prophet appeared

\section{Dan 12:2.}

26 As in Gen 42:38.

27 As in Deut 18:11.

28 Joshua J. Adler, 'The Bible and Life After Death', Jewish Bible Quarterly, 22:2 (1994), pp. 85-90; John Day, 'The Development of Belief in Life After Death in Ancient Israel', in After the Exile, ed. by John Barton and David J. Reimer (Macon, Ga.: Mercer University Press, 1996), pp. 231-57.

29 For general discussion, see Julius Guttman, Philosophies of Judaism, Eng. trans. by David W. Silverman (New York: Schocken, 1973), pp. 82-83.

30 bSanh. 90b-92b.

31 b̌́abb. 152b-153a.

32 For arguably the most famous story, see $b B e r$. 18a-18b.

33 bBer. 18b. 
to the necromancer upright rather than upside-down, which explains how the woman recognized Saul's attempt to deceive her by not identifying himself at the outset. The sages also comment on the cloak the undead prophet was wearing, asserting that it was the same cloak his mother made for him as a child, and the same cloak in which he was buried. But in both instances the rabbis raise exegetical questions - how the medium recognized Saul or why Samuel was wearing a cloak - that are solved with fairly characteristic methods of interpretation.

Keeping this background in mind, let us consider how Jews in medieval Ashkenaz viewed and explained the phenomenon of dead people coming back to life, and what mechanisms they employed to cope with the dangers posed by corporeal revenants. Writing on certain biblical and post-biblical texts about encounters between the living and the dead, Ashkenazi commentators explained such encounters and explored the nature of revenants by asking what precisely they are: spiritual entities lacking any physical attributes, or corporeal entities that are made of the real body parts of the deceased.

A text about the nature of revenants appears in a commentary on the Pentateuch written by the fourteenth-century Ashkenazi writer Menahem b. Me'ir Șiyyon. ${ }^{34}$ Commenting on the arrival of the three angels to visit Abraham (Gen. 18:1-22), Șiyyon explains the nature of prophetic revelations in general but also discusses in this context apparitions in biblical and post-biblical texts. The following passage is cited by Șiyyon but is attributed to Yehuda b. Shemuel of Regensburg (Yehuda He-Hasid, 1140-1217):

Regarding such instances as the vision of the necromancer in Endor, and concerning similar occurrences, Yehuda He-Hasid has maintained that if one were to search inside the grave no corporeal remains would have been found until after the revenant sheds its clothing (malbushaw). This is the meaning of the verse 'he feels only the pain of his flesh [and his spirit mourns in him].' 35 A spirit called 'animal spirit' (nefesh behemit) remains in the grave, mourning over its palace that returned to the ground. About this the sages say that 'worms are as painful to the dead as a needle in the flesh of the living' and speak allegorically about the lame and the blind. ${ }^{36}$ This is the interpretation of the words 'I see a divine being coming up from the earth', ${ }^{37}$ meaning that the spirit remains with the body in the grave but that the soul, which is 'bound up in the bundle of life' 38 , will not separate itself by the forces of impurity from the divine splendour. ${ }^{39}$

34 See the discussion about him in Israel J. Yuval, Hakhamim Be-Doram: Ha-Manhigut HaRuhanit shel Yehudei Germania Be-Shilhei Yemei Ha-Benayim (Jerusalem: Magnes Press, 1988), pp. 282-311.

35 Job 14:22.

36 bSanh. 91a-91b.

37 I Sam 28:13.

38 I Sam 25:29.

39 Menaḥem Șiyyon, Sefer Șiyyuni (Jerusalem, 1963), p. 10c. 
The key element in this passage is the animal spirit and its outer garment. The assertion that, were someone to search the grave of Samuel during his appearance to the medium at Endor, the prophet's corporeal remains would not have been found in the grave, suggests that the prophet's outer garments were ostensibly composed of the prophet's corporeal remains. This reading of the text is reaffirmed by the previous passage where, in explaining the talmudic story about Yehuda Ha-Nasi (c. 200 CE) appearing to his family every week, Șiyyon asserts that the Nasi's bones would doubtlessly have been found in the grave were one to have searched for them. 40 This suggests a difference of opinion regarding the nature of encounters with the dead. According to Yehuda He-Hasid, the dead may appear as revenants - physical entities embodying the animal spirit and the corporeal remains of the dead - whereas, according to Șiyyon, the dead may leave the grave only in the form of apparitions - spiritual entities composed of the spirit of the deceased clothed in outer garments that appear real but are, in reality, a mere illusion.

Before probing deeper into the belief in corporeal revenants, let us explore briefly Șiyyon's view and his likely source of influence. ${ }^{41}$ While Șiyyon himself never quite explains the mechanism by which a ghost can look real without being made of any tangible material, one should keep in mind the discussion of Ele'azar of Worms concerning the scent of the deceased. ${ }^{42}$ According to Ele'azar, after a person is buried and that person's soul departs the body, two entities remain in the grave: the person's spirit (ruah) and a quasi-physical entity referred to as scent (reah). Due to the quasi-physical characteristics of scent - being tangible and intangible at the same time - it surrounds the formless spirit, thereby giving it the appearance of a physical body. ${ }^{43}$ Ele'azar's concept of the corpse retaining the authentic and unique scent of the deceased originally appears in his discussion of the physical punishment of the wicked in hell. Rabbinic texts describe hell as a place where the souls of the wicked are burned but, if the soul is a metaphysical entity, how can it possibly be consumed by fire as a form of corporeal punishment? Ele'azar explains that what is being burned in hell is not merely the formless soul, that in itself cannot be subjected to any physical punishment, but rather the soul joined

40 Ibid.

41 For Ele'azar of Worms's impact on the work of Șiyyon, see Joseph Dan, Torat Ha-Sod shel Hasidut Ashkenaz (Jerusalem: Mosad Bialik, 1968), p. 259.

42 Hokhmat Ha-Nefesh (Șefat: 1913; repr. Jerusalem: 1968), pp. 5d-6a, 6d.

43 See Joshua Trachtenberg, Jewish Magic and Superstition: a Study in Folk Religion (Cleveland: Meridian Books, World Pub. Co., 1961), pp. 61-68. See also Moshe Idel, 'Gazing at the Head in Ashkenazi Hasidism', in The Journal of Jewish Thought and Philosophy, 6 (1997), pp. 289, 294-98. 
with the scent of the body that makes it possible to exact physical punishment from the wicked in the afterlife. ${ }^{44}$ Thus, by adopting Ele'azar's concept of scent, Șiyyon is attempting to explain the nature of apparitions.

Ashkenazi references to the biblical episode at Endor, and its relevance for their understanding of the phenomenon of revenants, parallel contemporary and earlier treatments of the topic by Christian writers. The approaches of Christian writers are succinctly summed up in the words of the twelfthcentury theologian Peter Comestor (d. 1169):

On the subject of this evocation some say that the evil spirit appeared looking like Samuel, or that it was his fantastic image (that is, raised up by the devil) that appeared there, which was called 'Samuel'. Others say that with God's permission it was indeed the soul of Samuel, covered by a body that appeared; but for others it was a body that was resuscitated and received the life of a spirit, while Samuel's soul remained in its resting place. 45

The multiple Christian interpretations of this biblical episode are also reflected in a series of iconographic representations. While in some illuminations Samuel appears as if he is still alive, walking and wearing ordinary clothing, ${ }^{46}$ in other artistic depictions he rises out of his grave wrapped in shrouds. ${ }^{47}$ In one image of the latter kind, Samuel's face is uncovered, the eyes and mouth are open, but the rest of the body is completely covered in shrouds, and he is standing upright in his grave. Similarly, in one fourteenth-century manuscript, Samuel is standing upright in his grave and the shrouds cover almost the entire body, but not his face. There is no clear evidence that Jewish writers were familiar with Christian texts or with Christian artistic representations of the topic but the possibility that Jews and Christians held in common beliefs about revenants remains plausible.

This may also be illustrated in a text from Sefer Hasidim that raises the question of how, when seeing a revenant, one can tell whether the revenant is the actual embodiment of the deceased or a pretender, that is, a demon appearing falsely and deceitfully in the image of the dead person. As the tale is told in one exemplum, a dead master appears to his servant and requests that the servant return the master's contested property, in order to alleviate any chastisement of the servant in the afterlife. When asked by the servant for verifica-

44 Hokhmat Ha-Nefesh, p. 7a. For a discussion of the mind-body duality in earlier rabbinic literature, see Nissan Rubin, The End of Life: Rites of Burial and Mourning in the Talmud and Midrash (Hebrew; Tel Aviv: Hakkibutz hameuchad, 1997), pp. 59-76.

45 Schmitt, Ghosts in the Middle Ages, p. 15.

46 Ibid., illustrations \# 1, 3, 5, and 6.

47 Ibid., illustrations \# 2 and 4. 
tion, the dead master promises to appear on a certain tree on the morrow and indeed he appears there as promised. In their effort to verify the true identity of this revenant, the people of the town search the master's grave and, as predicted, the corporeal remains of the master cannot be found. 48

What is most striking about this exemplum is the relatively neutral or indifferent tone employed by the writer to describe the undead Christian master. Rather than challenging the belief in revenants as a superstitious and credulous idea believed by Christians but not by Jews, the transmitter of the exemplum merely says 'true or not', meaning that there is no real way of verifying the truth, even by searching the grave to see if the body is still there. The writer of this exemplum remains modestly sceptical about revenants but does not altogether reject the phenomenon.

Jews (and non-Jews) who believed in revenants had to overcome the puzzling question of how bodies subjected to natural decay and degeneration can suddenly appear intact. The governing solution for this problem is the miraculous involvement of an omnipotent God in the process, which renders moot any questions about feasibility. More worldly solutions were, however, also offered, especially with regard to the issue of natural decay. One approach was to challenge in different ways the empirical assumption that the human body is always subject to corporeal decay after death. The persimmon, for example, was considered a deadly fruit that preserves the body of the person who would surely die after eating it. ${ }^{49}$ In addition, the religious status of the deceased, whether the person was considered righteous or wicked, was believed to have an impact on the state of the corporeal remains. The following quotation from a book describing the norms and customs of R. Shalom b. Yiṣhaq of Wiener Neustadt (d. 1413) demonstrates how religious status and the state of the corporeal remains were regarded as highly related issues in the minds of Jews and Christians alike:

Once an unmarried woman (betula) apostatized (nishtamda) in the Principality of Austria and died in her wickedness. They (the Christians) buried her in the churchyard (lit. 'in the courtyard of their idolatry'). After many years passed, they came to pile bones into a mound (of dry bones) as their custom and law dictates, but the flesh [of the woman] had not yet decomposed. They approached the extremely pious R. Shalom of Neustadt and inquired about the matter but he put them off. To his disciples, however, he explained that she was still being punished (in hell); and that only once her sin had been atoned, would the woman's flesh fully decompose [...] Yet, there is no reason to wonder about the pious people whose bodies remain intact in the grave even after they die. Quite

48 Sefer Hasidim, ed. by Judah Wistinetzki and Jacob Freimann (Berlin: H. Itzkowski, 1891), p. $37, \S 35$.

49 Sefer Hasidim, p. 101, §320-21. 
the contrary, this is the goodness and righteousness of the pious; they die instantly with the 'kiss of death' and their bodies remain intact until a short while prior to the resurrection of the dead. So I heard from my master and teacher Ya'aqov Moellin ('Maharil', ca. 1360-1427), may he rest in peace. ${ }^{50}$

The crux of this text is the belief of Jews and Christians alike in the connection between the state of the corporeal remains and the spiritual status of the deceased. It demonstrates that even an 'objective' empirical phenomenon such as the decomposition of the body after death was infused in the minds of medieval people with religious assumptions and, in this case, with polemical undertones as well. Such beliefs in the immunity of some dead to the process of natural decay clearly complicate any empirical assumptions that one might have about the fate of the corporeal remains after death. The case of the apostate woman is obviously an extreme one but it does show that the dichotomy between 'life' and 'death' was regarded as rather vague - at least concerning the spiritual status of the living and the fate of the body after death. ${ }^{51}$

Beliefs in revenant were often associated with concerns about their hazardous nature. That Jews in medieval Ashkenaz were anxious about revenants may be seen in various rituals, some of which seem quite bizarre to the modern reader. Sefer Hasidim prescribes a method for preventing a witch from causing harm by stabbing her with a stake in her (open) mouth or by filling her mouth with rocks..$^{52}$ Noteworthy is the underlying assumption that the same organ that causes the damage must be dealt with, in order to prevent such dangers from recurring. Therefore, the mouth of a woman whose children died in succession was filled with stones to prevent her from biting or eating any living beings, or a deceased witch's corpse was anchored to the ground to stop her ever leaving her grave and causing further damage.

While the treatment of the witch's body may seem extreme and unrepresentative, it was fairly common in Ashkenaz to confront the danger stemming from the dead through the recitation of special conjurations. What in Sefer Hasidim appears simply as an antidote for unexpected or undesirable encounters with the undead becomes in a later text - Hilkhot u-Minhagei Rabbenu

50 Hilkhot u-Minhagei Rabbenu Shalom mi-Noishtat, ed. by Shlomo Y. Spitzer (Jerusalem: Makhon Yerushalayim, 1996/7), p. 206, §2.

51 See Avriel Bar-Levav, 'The Concept of Death in Sefer Ha-Hayyim (The Book of Life) by Rabbi Shimon Frankfurt' (Hebrew; Jerusalem: doctoral dissertation, Hebrew University, 1997), pp. $125-35$.

52 Joseph Dan, 'Demonological Stories in the Writings of R. Yehuda He-Hasid', Tarbiz, 30:3 (1961), pp. 278-79, § 2; p. 280, §5. On witches in Sefer Hasidim, see Susanne Borchers, 'Hexen im "Sefer Hasidim”' in Henoch, 16.2-3 (1994), pp. 271-93. 
Shalom mi-Noishtat - part of the funerary ceremony to be recited in the presence of a quorum (minyan). The conjuration includes the following text:

\begin{abstract}
'In the name of the heavenly court, in the name of the earthly court, and in the name of so-and-so, I conjure you in the name of the God of heaven and earth and all His holy names that you will not kill any person [lit. bring with you], neither man nor woman, neither minor nor adult, neither a relative nor a stranger. Cause them no harm either with your body or with your spirit or soul. Your body must remain in the grave until the resurrection of the dead. Your soul should remain in its proper place and likewise your spirit should remain in its proper place. You should take an oath with sanctions from now until the end of days.' Following the ceremony the participants replied 'Amen'. I saw that they conjured the father-in-law of Shalom [of Neustadt] at the house where the bodies of the dead are ritually cleansed before the ritual cleansing in the present of ten people. On another occasion I saw that they conjured the great-granddaughter of Shalom's wife in his courtyard where they left the body on the ground before carrying her to the cemetery. ${ }^{53}$
\end{abstract}

This ritual conjuration recited before the body of the deceased and in the presence of ten men, who upon hearing it responded 'amen', reveals concrete fears about the re-appearance of the dead. Strikingly, the people at whose funerals the conjuration is reported to have been recited are none other than the father-in-law of Shalom of Neustadt's child, and the great grandchild of a female neighbour of Shalom of Neustadt. This suggests that concerns about the hazardous potential of revenants was not restricted to distinct elements in Jewish society (such as criminals or, not to mention the two in the same breath, women) but included men and women, young and adult, distinguished and less distinguished people alike.

References to dead bodies departing physically from their graves appear as a matter of fact in at least two halakhic texts. The texts formally discuss prohibitions concerning sorcery and magic. Any communication with a dead corpse (doresh el ha-metim) - either when the body remains in the grave, or in the case of necromancy, which involves communicating with a body that has left the grave - is considered an idolatry and is, therefore, strictly prohibited. If, however, one requests a dying person to appear after death, or attempts to communicate with the spirit of the dead (doresh le-ruho) this is not prohibited, since communicating with the spirit of the dead is not the same as communicating with the body of the deceased. ${ }^{54}$

53 Hilkhot u-Minhagei Rabbenu Shalom mi-Noishtat (Jerusalem: Makhon Yerushalayim, 1996), pp. 159-60 (§544).

54 Eli‘ezer b. Shemuel of Metz, Sefer Yere'im, ed. by Abraham A. Schiff (Vilna: Katzenellenbogen, 1892-1904), pp. 187a-187b, §334-335. 


\title{
3 In conclusion
}

In conclusion, I would like to discuss briefly another practice that may not seem at first glance related, but a closer look will reveal the connection. This practice, too, appears in the compilation of rulings and customs of Hilkhot $\mathrm{u}$ Minhagei Shalom mi-Noishtat. The custom concerns the ritual discarding of the foreskin after circumcision:

\begin{abstract}
'Who can ascend to the heaven for us?' 55 I heard from R. Shalom that [the first letters of the words in this quotation] form the acronym MILA (circumcision). When Ashkenazim circumcise a child they cast the child's foreskin in a hole dug under the ark since they believe that the foreskin ascends to heaven. This is the true meaning of R. Shalom's comment about the acronym of the verse. [Note also that] the last letters of the words in this verse, YHWH, form the name of God.
\end{abstract}

In an article entitled 'Marking the Flesh', Elisheva Baumgarten describes two traditions concerning the disposal of the foreskin after circumcision. The first involved circumcising the child over sand or water after which the foreskin was buried, and the second permitted barren women to swallow the foreskin after they attend a circumcision ritual as a way of inducing fertility. ${ }^{56}$ In addition to the two practices mentioned by Baumgarten one should add a third one reported in the text above concerning R. Shalom. Rather than being buried in the ground or swallowed, the foreskin was kept in a locus sanctus under the ark. It should be mentioned that according to this text, the custom was practised by Ashkenazim of other localities and not only by the community of Wiener-Neustadt. This rather obscure custom raises many questions. What is the purpose of casting foreskins into a hole under the ark? How can foreskins or, for that matter, any other objects ascend to heaven? Is the designation of a location underneath the ark for disposal related to the Christian tradition of burying the most elevated saints and ecclesiastical figures under the altar?

This custom clearly merits a separate and longer discussion but I would like to call attention to the confluence of a bodily object - the foreskin - with the heavenly world. As with the earthly soul of the deceased that resides with the corporeal remains in the grave, or the phenomenon of revenants, here too the boundaries between a corporeal object - the foreskin - and the heavenly world are crossed and become blurred. In a reversal of terms, just as the spirit of the dead remains in the earthly world after death, so too the bodily object,

55 Deut 30:12.

56 Elisheva Baumgarten, 'Marking the Flesh: Circumcision, Blood, and Inscribing Identity on the Body in Medieval Jewish Culture', Micrologus, 13 (2005), pp. 313-30. 
the foreskin, 'resides' in the spiritual, heavenly world. In both instances, the heavenly and the worldly intersect, not in the unknown eschatological future but in the immediate future, in the here and now. 
